\title{
Analysis of innovation in the MIPYMES of León, Guanajuato, Mexico, during and post-covid-19
}

\section{Análisis de la innovación en las MIPYMES de León, Guanajuato, México, durante y post-covid-19}

SERRANO-TORRES, Ma. Guadalupe ${ }^{1}$, QUEZADA-FLORES, Ma. De la Luz ${ }^{1}$, MARTINEZBECERRA, Abel Manuel ${ }^{1}$ and ZAMBRANO-VALDIVIEZO, Oscar Javier ${ }^{2}$

${ }^{1}$ Universidqd Tecnologica de León

${ }^{2}$ Corporación Universitaria Minuto de DIOS- UNIMINUTO, Santander Colombia

ID $1^{\text {st }}$ Author: Ma. Guadalupe, Serrano-Torres / ORC ID: 0000-0003-2229-6925, CVU CONACYT ID: 679788

ID $1^{\text {st }}$ Co-author: Ma. de la Luz, Quezada-Flores / ORC ID: 0000-0002-4726-2695, CVU CONACYT ID: 801109

ID $2^{\text {nd }}$ Co-author: Abel Manuel, Martinez-Becerra / ORC ID: 0000-0002-8967-580X, CVU CONACYT ID: 1173021

ID $3^{\text {rd }}$ Co-author: Oscar Javier Zambrano Valdiviezo / ORC ID: 0000-0003-0064-1062

DOI: $10.35429 / J L D E .2019 .5 .3 .1 .6$

Received July 28, 2019; Accepted December 21, 2019

\begin{abstract}
The objective of this research is to analyze the main survival strategy during and after the pandemic of MIPYMES, which is undoubtedly innovation, it will analyze flugal innovation, open innovation and innovation in general of micro, small and medium-sized companies, Without a doubt, these types of companies represent the backbone of the economy in the world and in Mexico, especially in León, Guanajuato, the term innovation was used during and after the covid-19 pandemic by companies as a strategy to survive and adapt in the production processes and in the commercialization of their products, the innovation of the companies will be analyzed through the application of 350 surveys to the MIPYMES the grounded methodology is used, the research is quantitative because it measures the level of innovation that the Directors and owners of this type of company perceive they have had in their company. In the international innovation indices, Mexico is at the 55th place in the annual ranking by 2021. The result is that MIPYMES used innovation as a survival tool, to stay alive and maintain their production and marketing of their products.
\end{abstract}

Open innovation, Frugal innovation and innovation

\begin{abstract}
Resumen
La presente investigación tiene por objetivo analizar la principal estrategia de supervivencia durante y post pandemia de las MIPYMES, que sin duda es la innovación, se análizara la innovación flugal, la innovación abierta y la innovación en general de las micro, pequeñas y medianas empresas, sin lugar a duda este tipo de empresas representan la columna vertebral de la economía en el mundo y en México, en especial en León, Guanajuato, el termino innovación fue empleado durante y post la pandemia covid-19 por las empresas como una estrategia para sobrevivir y adaptarse en los procesos productivos y en la comercialización de sus productos, se analizará la innovación de las empresas mediante la aplicación de 350 encuestas a las MIPYMES, se utiliza la metodología fundamentada, la investigación es cuantitativa por que mide el nivel de innovación que los directores y dueños de este tipo de empresa perciben haber tenido en su empresa. En los índices internacionales de innovación México se encuentra al año 2021 en el sitio 55 en el ranking anual, Se obtiene como resultado que las MIPYMES utilizaron como herramienta de supervivencia la innovación, para seguir vivas y mantener su producción y comercialización de sus productos.
\end{abstract}

Innovación abierta, Innovación frugal e innovación

Citation: SERRANO-TORRES, Ma. Guadalupe, QUEZADA-FLORES, Ma. De la Luz, MARTINEZ-BECERRA, Abel Manuel and ZAMBRANO-VALDIVIEZO, Oscar Javier. Analysis of innovation in the MIPYMES of León, Guanajuato, Mexico, during and post-covid-19. Journal-Labor and Demographic economics. 2021. 5-9: 1-14

\footnotetext{
* Correspondence to Author (email: edithmejia@utng.edu.mx)

$\dagger$ Researcher contributing first author.
} 


\section{Introduction}

It is very important to mention that the pandemic covid-19 is still present, that it is a phenomenon with which we are going to live at least until the whole world is vaccinated, economically we are living the consequences generated by this pandemic. Therefore, our objective of study is innovation, it is a very important subject of study, because it represents one of the necessary options of survival for many companies and its use was and is indispensable during and post pandemic covid-19, in order to survive the managers and owners of such companies, had to adopt the different terms of innovation among them is open innovation, frugal innovation and innovation in general terms.

The pandemic has not passed, neither economically nor in a sanitary way, in spite of the fact that vaccines for this disease have been applied and continue to be applied all over the world. MSMEs around the world received support and financing during the most difficult months of confinement and partial closures due to the confinement. Mexico was no exception. MSMEs were supported with economic aid, with projects to generate income for families through loans and donations.

The Ministry of Economy published calls for proposals where simple self-employment and business projects could be developed, for example, to set up taco, tamale and similar stalls, and interest-free loans were offered to be returned in an accessible manner. Now, despite the support and economic and health struggle, COVID-19 is present and the economic crisis will gradually withdraw step by step, and it will be an integral task of government, educational institutions, other organizations to support businesses and owners and managers, to eradicate as quickly as possible the economic aftermath that has left us the pandemic covid-19.

For the month of March of the year 2020 in the world the biggest isolation in history took place, and was characterized by the dismissal of many employees, temporary closure of most companies, only remained open the essential companies such as supermarkets and health, now it was in this isolation when companies around the world had to innovate their way of working from home, their way of producing, marketing their products and services.
It is worth mentioning that a large percentage of the companies in the study could not bear the burden of paying fixed costs and expenses such as payroll, rents and other expenses even when the company was not working and closed its doors forever.

Well, hence the importance of analyzing how the managers and owners of MSMEs in Leon, Guanajuato, Mexico, handled innovation during and after COVID-19. During the first red traffic light. And the gradual change of traffic lights from yellow to orange and finally in December some states are again in red traffic light, for the beginning of the year 2021 it starts again with orange and yellow traffic light and for the last months of the year most of the states are already in green traffic light, but with a new knowledge for the month of December this virus is already found in 51 countries and in Mexico for December 3 the first confirmed case of Omicron is found. According to the newspaper el (país, 2021). Undoubtedly, another new sanitary and economic challenge for Mexican companies.

The central question of this research is: Did MSMEs change and innovate their way of producing and marketing their products and use sustainability during and after the covid-19 pandemic?

The data collection was carried out in October 2021 in the city of Leon, Guanajuato, Mexico to know the management of open innovation, frugal innovation and innovation in general of MSMEs during and post covid-19.

\subsection{Justification}

The present research aims to analyze the innovation of MSMEs during and post covid-19 in Leon, Guanajuato, Mexico. The management given by the directors and owners of this type of companies to the aspects of open innovation, frugal innovation and innovation in general terms, in order to take care of the financial, cost and sustainable development aspects.

Their high business representation in Mexico, with $99.8 \%$ of the total number of companies, represents the backbone of the country's economy. However, these companies have gone through economic crises such as the covid-19 and now with the new omicron strain and continue to operate, this is due to the family roots that most MSMEs have.

SERRANO-TORRES, Ma. Guadalupe, QUEZADA-FLORES, Ma. De la LuZ, MARTINEZ-BECERRA, Abel Manuel and ZAMBRANO-VALDIVIEZO, Oscar Javier. Analysis of innovation in the MIPYMES of León, Guanajuato, Mexico, during and post-covid-19. Journal-Labor and Demographic economics. 2021 


\subsection{Problem}

Since March 2020 and to date, covid-19 has caused a worldwide economic and health crisis and for the companies in Leon, Guanajuato, Mexico is no exception, so the MSMEs were forced to use and implement innovation, many of them closed their doors for good and those that are still alive had to adapt their production and financial processes to live with this phenomenon that affects all companies. And now with the new omicron virus.

\subsection{Research questions}

a. Has the company become more innovative in recent months compared to its competitors?

b. External sources of knowledge and technology were sought to develop new products?

c. Does my company use alliances with local companies in its operational process?

\subsection{Hypothesis}

Micro, small and medium enterprises in Leon, Guanajuato, do not have the levels of open and frugal innovation, during and after the covid-19 pandemic.

\subsection{General Objective}

To analyze the innovation acceptance of micro, small and medium-sized enterprises during and post covid-19 pandemic.

\section{Theoretical framework.}

\subsection{Current situation of innovation at the international level}

The following table number one shows the most innovative countries worldwide, as of September 2021. In the first 10 places we find: Switzerland, Sweden, United States, United Kingdom, Republic of Korea, Netherlands, Finland, Singapore, Denmark and Germany. (WIPO, 2021).
Analysis of Mexico's innovation with the other 132 countries. We occupy the 55th place of the countries analyzed in the International Innovation Index (WIPO 2021). It is worth mentioning that Mexico moved up one place to 56th place, which shows that this pandemic made us change rapidly in the way we produce and market our products. In 54th place we have Serbia and in 56th place Costa Rica, our closest competitors in innovation.

\begin{tabular}{|c|c|}
\hline Index & Country \\
\hline 1 & Switzerland \\
\hline 2 & Sweden \\
\hline 3 & United States of America \\
\hline 4 & United Kingdom \\
\hline 5 & Republic of Korea \\
\hline 6 & Netherlands \\
\hline 7 & Finlandia \\
\hline 8 & Singapur \\
\hline 9 & Dinamarca \\
\hline 10 & Alemania \\
\hline 11 & Francia \\
\hline 12 & China \\
\hline 13 & Japón \\
\hline 14 & Hong Kong, China \\
\hline 15 & Israel \\
\hline 16 & Canadá \\
\hline 17 & Islandia \\
\hline 18 & Austria \\
\hline 19 & Irlanda \\
\hline 20 & Noruega \\
\hline 21 & Estonia \\
\hline 22 & Bélgica \\
\hline 23 & Luxemburgo \\
\hline 24 & Republica checa \\
\hline 25 & Australia \\
\hline 26 & Nueva Zelanda \\
\hline 27 & Malta \\
\hline 28 & Chipre \\
\hline 29 & Italia \\
\hline 30 & España \\
\hline 31 & Portugal \\
\hline 32 & Eslovenia \\
\hline 33 & Emiratos Árabes Unidos \\
\hline 34 & Hungría \\
\hline 35 & Bulgaria \\
\hline 36 & Malasia \\
\hline 37 & Eslovaquia \\
\hline 38 & Letonia \\
\hline 39 & Lituania \\
\hline 40 & Polonia \\
\hline 41 & Pavo \\
\hline 42 & Croacia \\
\hline 43 & Tailandia \\
\hline 44 & Vietnam \\
\hline 45 & Federación Rusa \\
\hline 46 & India \\
\hline 47 & Grecia \\
\hline 48 & Rumania \\
\hline 49 & Ucrania \\
\hline 50 & Montenegro \\
\hline 51 & Filipinas \\
\hline
\end{tabular}

SERRANO-TORRES, Ma. Guadalupe, QUEZADA-FLORES, Ma. De la Luz, MARTINEZ-BECERRA, Abel Manuel and ZAMBRANO-VALDIVIEZO, Oscar Javier. Analysis of innovation in the MIPYMES of León, Guanajuato, Mexico, during and post-covid-19. Journal-Labor and Demographic economics. 2021 


\begin{tabular}{|c|c|}
\hline 52 & Mauricio \\
\hline 53 & Chile \\
\hline 54 & Serbia \\
\hline 55 & Mexico \\
\hline 56 & Costa Rica \\
\hline 57 & Brasil \\
\hline 58 & Mongolia \\
\hline 59 & Macedonia del Norte \\
\hline 60 & Irán (República Islámica de) \\
\hline 61 & Sudáfrica \\
\hline 62 & Bielorrusia \\
\hline 63 & Georgia \\
\hline 64 & República de Moldova \\
\hline 65 & Uruguay \\
\hline 66 & Arabia Saudita \\
\hline 67 & Colombia \\
\hline 68 & Katar \\
\hline 69 & Armenia \\
\hline 70 & Perú \\
\hline 71 & Túnez \\
\hline 72 & Kuwait \\
\hline 73 & Argentina \\
\hline 74 & Jamaica \\
\hline 75 & Bosnia y Herzegovina \\
\hline 76 & Omán \\
\hline 77 & Marruecos \\
\hline 78 & Bahréin \\
\hline 79 & Kazajstán \\
\hline 80 & Azerbaiyán \\
\hline 81 & Jordán \\
\hline 82 & Brunei Darussalam \\
\hline 83 & Panamá \\
\hline 84 & Albania \\
\hline 85 & Kenia \\
\hline 86 & Uzbekistan \\
\hline 87 & Indonesia \\
\hline 88 & Paraguay \\
\hline 89 & Cabo Verde \\
\hline 90 & República Unida de Tanzania \\
\hline 91 & Ecuador \\
\hline 92 & Líbano \\
\hline 93 & República Dominicana \\
\hline 94 & Egipto \\
\hline 95 & Sri Lanka \\
\hline 96 & El Salvador \\
\hline 97 & Trinidad y Tobago \\
\hline 98 & Kirguistán \\
\hline 99 & Pakistán \\
\hline 100 & Namibia \\
\hline 101 & Guatemala \\
\hline 102 & Ruanda \\
\hline 103 & Tayikistán \\
\hline 104 & Bolivia (Estado Plurinacional de) \\
\hline 105 & Senegal \\
\hline 106 & Botswana \\
\hline 107 & Malawi \\
\hline 108 & Honduras \\
\hline 109 & Camboya \\
\hline 110 & Madagascar \\
\hline 111 & Nepal \\
\hline 112 & Ghana \\
\hline 113 & Zimbabue \\
\hline 114 & Costa de Marfil \\
\hline 115 & Burkina Faso \\
\hline 116 & Bangladesh \\
\hline
\end{tabular}

\begin{tabular}{|l|l|}
\hline 117 & República Democrática Popular Lao \\
\hline 118 & Nigeria \\
\hline 119 & Uganda \\
\hline 120 & Argelia \\
\hline 121 & Zambia \\
\hline 122 & Mozambique \\
\hline 123 & Camerún \\
\hline 124 & Mali \\
\hline 125 & Togo \\
\hline 126 & Etiopía \\
\hline 127 & Myanmar \\
\hline 128 & Benin \\
\hline 129 & Níger \\
\hline 130 & Guinea \\
\hline 131 & Yemen \\
\hline 132 & Angola \\
\hline
\end{tabular}

Table 1 International innovation index Source: Own Elaboration with WIPO 2021 data

The cities in Mexico considered to have the most innovation and technology for (NEUBOX, 2021), in first place is Guadalajara considered the Solicon Valley of MexicoIBM, HP and Intel, collaborating in the development of the country's technology sector, in second place is the city of Mexico considered the most industrialized of the country, which aims to be the seventh global economic hub, in third place Monterrey with more than 100 industrial parks Neoris opened its innovation laboratory to boost the digital transformation of the city, In fourth place is the city of Tijuana, which is a 20 minute drive from the United States and its gross domestic product is comparable to Ireland's. In fifth place is Queretaro, located in the center of the country with the MAFTA highway development, through which many of the economic activities at national level pass, this brought with it the aerospace development, turning Queretaro into a new center for the aerospace industry.

\subsection{Open innovation}

First of all, let's talk about closed innovation, which represents the internal way of innovating within the company, with the ideas and materials of the entity, the core of developing products and services, with the human, technological and material resources the company has. Well, open innovation opens the doors to educational institutions to external advisors from Mexico and the world, working together closed innovation with open innovation without leaving frugal innovation, we can make the most of the opportunity to develop innovation in our companies, localities, states, countries and the whole world.

SERRANO-TORRES, Ma. Guadalupe, QUEZADA-FLORES, Ma. De la Luz, MARTINEZ-BECERRA, Abel Manuel and ZAMBRANO-VALDIVIEZO, Oscar Javier. Analysis of innovation in the MIPYMES of León, Guanajuato, Mexico, during and post-covid-19. Journal-Labor and Demographic economics. 2021 
Now, for Proum (2020), Mexican SMEs are in great economic affectation, this putting as background that the virus was born in the province of Wuhan, China and without losing sight of the bilateral relationship that exists between the two countries.

For (Calderon, 2010). Open innovation is the openness to cooperation is translated into contracts or agreements to carry out innovation in the administration or processes of the organization that requests the collaboration.

Now, another author who studies the relationship of innovation from the external aspect and the relationship of organizations with external actors is (Laursen, 2006). Analyzing the benefits of having a collaboration with external for the external innovation aspects of the company.

Well, internal and external innovation combined can produce better results than internally generated innovation. And even more so in this economic crisis caused by covid- 19 .

\subsection{Frugal innovation}

Undoubtedly, innovation is the most important tool that every company must develop to mitigate the economic impact brought about by the global pandemic, so we rely on flugal innovation that supports the questions raised by this research, and used by Japan to surpass the United States in the production of cars. Now, an author who supports this type of innovation is Basu, Banergee and Swenny (2013). Where he mentions the main characteristics that a frugal innovation must meet.

In his article, he states: "basic characteristics of a frugal innovation and how they relate to the classic innovation model".

Thus, the research instrument questions are shaped by open innovation, frugal innovation and innovation in general.

These characteristics are: being resilient, lightweight, mobile, human-focused, simplified, with new distribution models, use of local resources, green and affordable technologies.

\section{Methodology to be developed}

The present research is quantitative, 350 surveys were applied to the managers and owners of the MSMEs of Leon Guanajuato, the students of the economic-administrative area of the careers of administration and gastronomy mainly, were the ones who applied the surveys in person and captured it in the database of the network of technological universities, this same instrument was applied nationally by all the Technological Universities that participated in the network of research of crisis post covid-19. The instrument consisted of a total of 15 blocks, block four being the analysis of this research. It consisted of 19 items of general innovation, open innovation and frugal innovation.

\section{Results}

The following are the results of the application of 350 surveys to MSMEs in the city of Leon, Guanajuato, Mexico, applied to managers and owners, regarding block four corresponding to innovation with respect to internal and external sources of technologies, costs, finances and production during and post covid-19.

The following are the results of open innovation, which consists of 8 itms corresponding to this type of innovation of the MSMEs of Leon, Guanajuato, Mexico.

Table 2 below shows the response to the question "my company constantly scans the external environment for inputs such as technology, information, ideas and knowledge". As a result, only $18.3 \%$ of the directors and owners of the MSMEs agree in seeking external inputs.

\begin{tabular}{|l|r|r|r|}
\hline \multicolumn{1}{|c}{ Description } & Number & \multicolumn{1}{c}{$\begin{array}{c}\text { Percentage } \\
\text { \% }\end{array}$} & $\begin{array}{c}\text { Cumulative } \\
\text { Percentage \% }\end{array}$ \\
\hline Total agreement & 25 & 7.1 & 7.1 \\
\hline Agreed & 39 & 11.1 & 18.3 \\
\hline $\begin{array}{l}\text { Neither agree nor } \\
\text { disagree }\end{array}$ & 86 & 24.6 & 42.9 \\
\hline Disagree & 102 & 29.1 & 72.0 \\
\hline Total disagreement & 98 & 28.0 & 100.0 \\
\hline Total surveys applied & 350 & 100.0 & \\
\hline
\end{tabular}

Table 2 my company constantly scans the external environment for inputs such as technology, information, ideas, and knowledge.

Source: Own Elaboration 


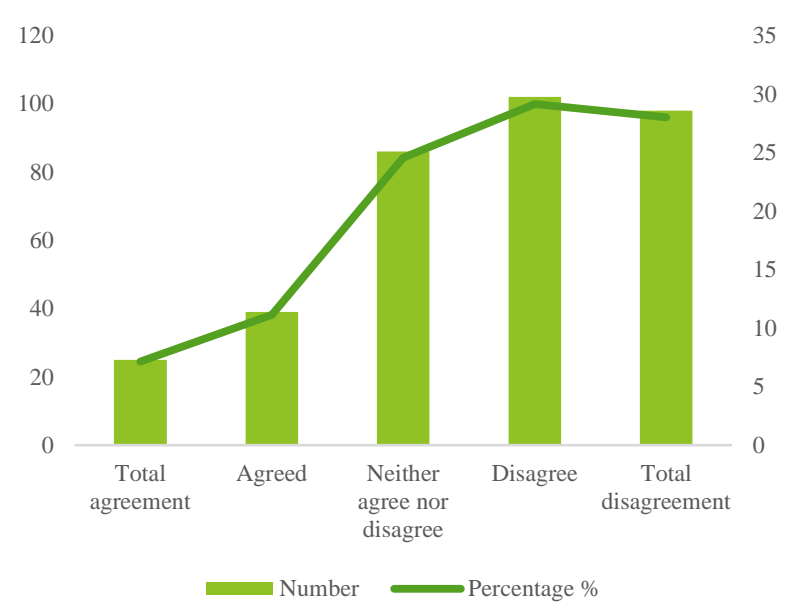

Graph 1 My company constantly scans the external environment for inputs such as technology, information, ideas, and knowledge.

Source: Own Elaboration

The following table number three shows how the managers of the MSMEs perceive the external search for technology and external knowledge for the generation of new products and only $23.1 \%$ agree that they have externally searched for knowledge and technology outside the company.

\begin{tabular}{|l|r|r|r|}
\hline \multicolumn{1}{|c|}{ Description } & Number & $\begin{array}{c}\text { Percentage } \\
\text { \% }\end{array}$ & $\begin{array}{c}\text { Cumulative } \\
\text { Percentage \% }\end{array}$ \\
\hline Total agreement & 39 & 11.1 & 11.1 \\
\hline Agreed & 42 & 12.0 & 23.1 \\
\hline $\begin{array}{l}\text { Neither agree nor } \\
\text { disagree }\end{array}$ & 87 & 24.9 & 48.0 \\
\hline Disagree & 113 & 32.3 & 80.3 \\
\hline Total disagreement & 69 & 19.7 & 100.0 \\
\hline Total surveys applied & 350 & 100.0 & \\
\hline
\end{tabular}

Table 3 My company effectively seeks external sources of knowledge and technology to develop new products. Source: Own Elaboration

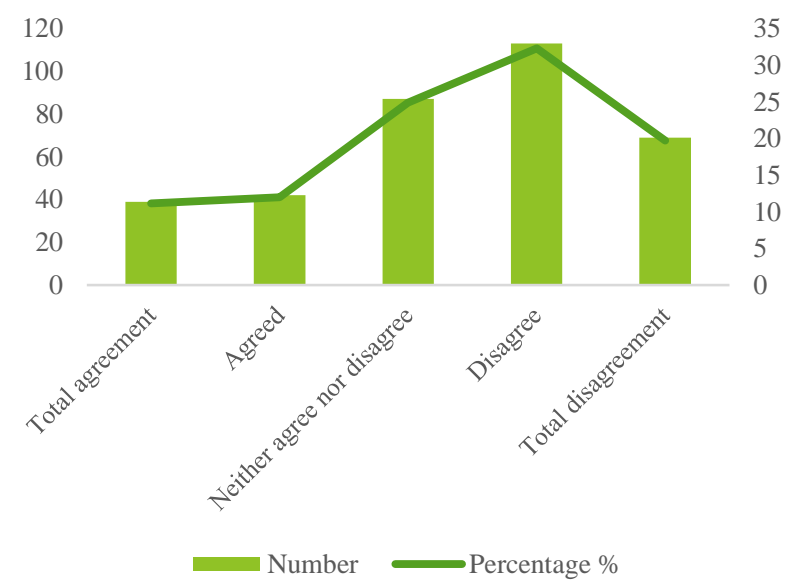

Graph 2 My company effectively seeks external sources of knowledge and technology to develop new products Source: Own Elaboration
The following table number four shows how the managers of the companies under study perceive whether it is good to use external sources of knowledge, customers, suppliers and competitors. Only $22 \%$ believe that they agree with the use of external sources.

\begin{tabular}{|c|c|c|c|}
\hline Description & Number & $\begin{array}{c}\text { Percentage } \\
\%\end{array}$ & $\begin{array}{c}\text { Cumulative } \\
\text { Percentage \% }\end{array}$ \\
\hline Total agreement & 34 & 9.7 & 9.7 \\
\hline Agreed & 43 & 12.3 & 22.0 \\
\hline $\begin{array}{ll}\begin{array}{l}\text { Neither agree nor } \\
\text { disagree }\end{array} & \\
\end{array}$ & 89 & 25.4 & 47.4 \\
\hline Disagree & 109 & 31.1 & 78.6 \\
\hline Total disagreement & 75 & 21.4 & 100.0 \\
\hline Total surveys applied & 350 & 100.0 & \\
\hline
\end{tabular}

Table 4 My company believes it is good to use external sources of research, customers, suppliers and competitors Source: Own Elaboration

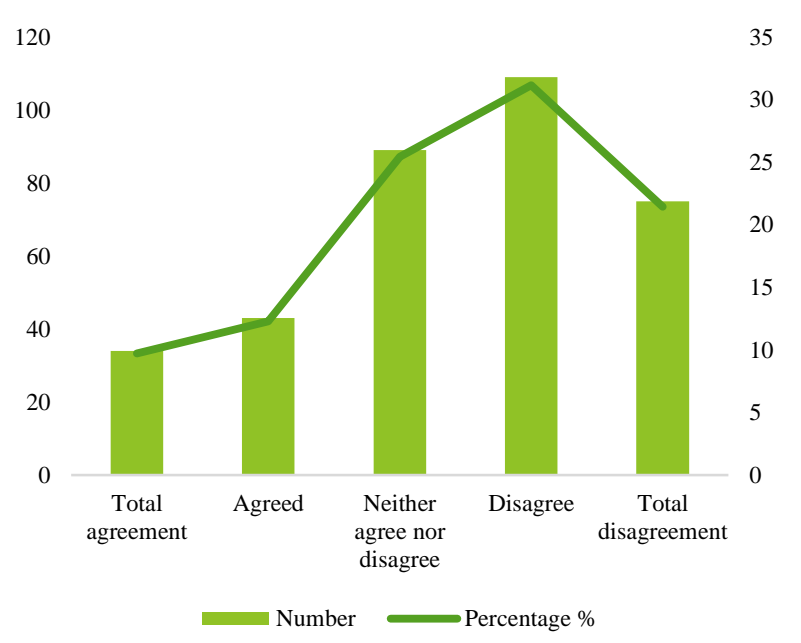

Graph 3 My company believes it is good to use external research sources, customers, suppliers and competitors

Source: Own Elaboration

In this table number five, it is shown how the managers of the MSMEs perceive that they have received external advice and $27.1 \%$ agree that they have used external advice to combine it with internal technology.

\begin{tabular}{|l|r|r|r|}
\hline \multicolumn{1}{|c|}{ Description } & Number & $\begin{array}{c}\text { Percentage } \\
\%\end{array}$ & $\begin{array}{c}\text { Cumulative } \\
\text { Percentage \% }\end{array}$ \\
\hline Total agreement & 46 & 13.1 & 13.1 \\
\hline Agreed & 49 & 14.0 & 27.1 \\
\hline $\begin{array}{l}\text { Neither agree nor } \\
\text { disagree }\end{array}$ & 102 & 29.1 & 56.3 \\
\hline Disagree & 97 & 27.7 & 84.0 \\
\hline Total disagreement & 56 & 16.0 & 100.0 \\
\hline Total surveys applied & 350 & 100.0 & \\
\hline
\end{tabular}

Table 5 My company often brings in externally developed knowledge and technology for use in conjunction with our own research and development Source: Own Elaboration 


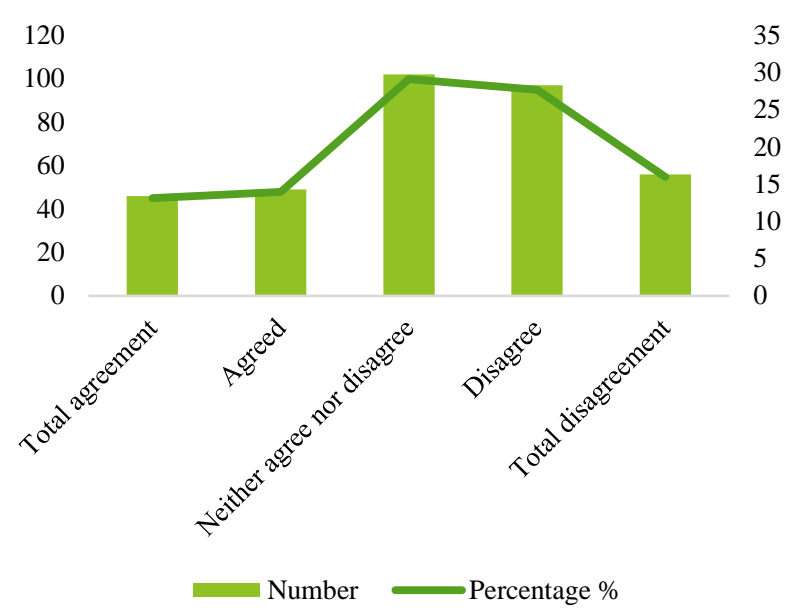

Graph 4 My company often brings in externally developed knowledge and technology to use in conjunction with our own research and development

Source: Own Elaboration

This table shows that entrepreneurs perceive that they have sought technology, research groups and patents from other companies, $41 \%$ agree that they have sought external support during and post-covid-19.

\begin{tabular}{|l|r|r|r|}
\hline \multicolumn{1}{|c|}{ Description } & \multicolumn{1}{c|}{ Number } & $\begin{array}{c}\text { Percentage } \\
\text { \% }\end{array}$ & $\begin{array}{c}\text { Cumulative } \\
\text { Percentage \% }\end{array}$ \\
\hline Total agreement & 78 & 22.3 & 22.3 \\
\hline Agreed nor & 67 & 19.1 & 41.4 \\
\hline $\begin{array}{l}\text { Neither agree } \\
\text { disagree }\end{array}$ & 97 & 27.7 & 69.1 \\
\hline Disagree & 68 & 19.4 & 88.6 \\
\hline Total disagreement & 40 & 11.4 & 100.0 \\
\hline Total surveys applied & 350 & 100.0 & \\
\hline
\end{tabular}

Table 6 My organization seeks technologies and patents from other organizations, research groups or universities Source: Own Elaboration

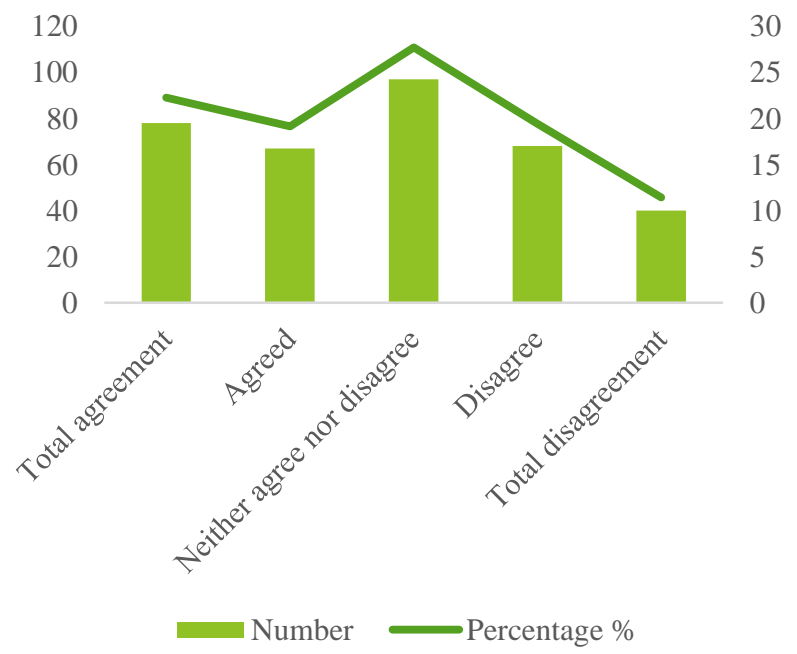

Graph 5 My organization seeks technologies and patents from other organizations, research groups or universities Source: Own Elaboration
This table shows that $47.4 \%$ of the entrepreneurs perceive that they obtained external intellectual property to combine it with their own.

\begin{tabular}{|l|r|r|r|}
\hline \multicolumn{1}{|c|}{ Description } & Number & $\begin{array}{c}\text { Percentage } \\
\text { \% }\end{array}$ & $\begin{array}{c}\text { Cumulative } \\
\text { Percentage \% }\end{array}$ \\
\hline Total agreement & 94 & 26.9 & 26.9 \\
\hline Agreed & 72 & 20.6 & 47.4 \\
\hline $\begin{array}{l}\text { Neither agree nor } \\
\text { disagree }\end{array}$ & 100 & 28.6 & 76.0 \\
\hline Disagree & 53 & 15.1 & 91.1 \\
\hline Total disagreement & 31 & 8.9 & 100.0 \\
\hline Total surveys applied & 350 & 100.0 & \\
\hline
\end{tabular}

Table 7 My organization buys external intellectual property for use in its own organization Source: Own Elaboration

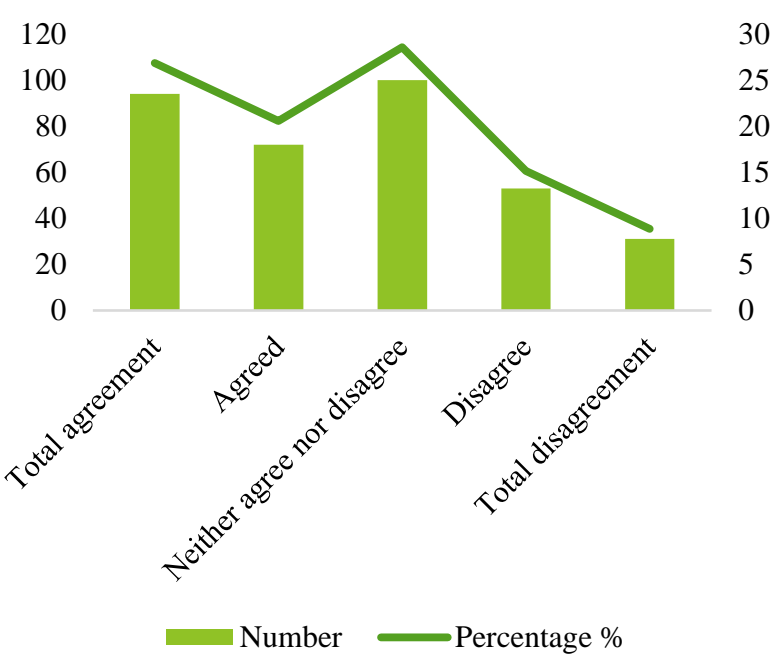

Graph 6 My organization buys external intellectual property for use in its own organization

Source: Prepared by the organization

Now in the next block it is time to analyze competitiveness according to the costs of products, raw materials and services.

The following table shows that $48 \%$ of managers agree that technologies are marketed externally.

\begin{tabular}{|l|r|r|r|}
\hline \multicolumn{1}{|c|}{ Description } & \multicolumn{1}{c}{ Number } & $\begin{array}{c}\text { Percentage } \\
\%\end{array}$ & $\begin{array}{c}\text { Cumulative } \\
\text { Percentage \% }\end{array}$ \\
\hline Total agreement & 104 & 29.7 & 29.7 \\
\hline Agreed & 66 & 18.9 & 48.6 \\
\hline $\begin{array}{l}\text { Neither agree nor } \\
\text { disagree }\end{array}$ & 67 & 19.1 & 67.7 \\
\hline Disagree & 67 & 19.1 & 86.9 \\
\hline Total disagreement & 46 & 13.1 & 100.0 \\
\hline Total surveys applied & 350 & 100.0 & \\
\hline
\end{tabular}

Table 8 Generally, in my company all technologies are marketed externally

Source: Own Elaboration 


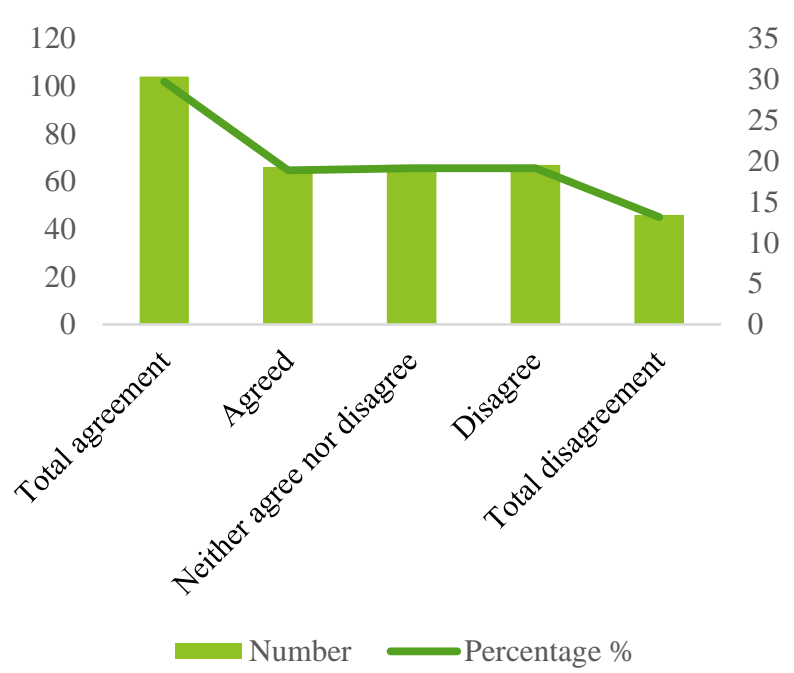

Graph 7 Generally in my company all technologies are marketed externally

Source: Prepared by the company

This table shows that managers and owners of MSMEs perceive that technology in their companies is restricted to external technologies that are not used internally. And $45.4 \%$ agree.

\begin{tabular}{|l|r|r|r|}
\hline \multicolumn{1}{|c|}{ Description } & \multicolumn{1}{r|}{$\begin{array}{r}\text { Number } \\
\text { \% }\end{array}$} & $\begin{array}{c}\text { Percentage } \\
\text { Cumulative } \\
\text { Percentage \% }\end{array}$ \\
\hline Total agreement & 91 & 26.0 & 26.0 \\
\hline Agreed nor & 68 & 19.4 & 45.4 \\
\hline $\begin{array}{l}\text { Neither agree nor } \\
\text { disagree }\end{array}$ & 107 & 30.6 & 76.0 \\
\hline Disagree & 59 & 16.9 & 92.9 \\
\hline Total disagreement & 25 & 7.1 & 100.0 \\
\hline Total surveys applied & 350 & 100.0 & \\
\hline
\end{tabular}

Table 9 In my company, the commercialization of external technology is restricted to technologies that are not used internally

Source: Own Elaboration

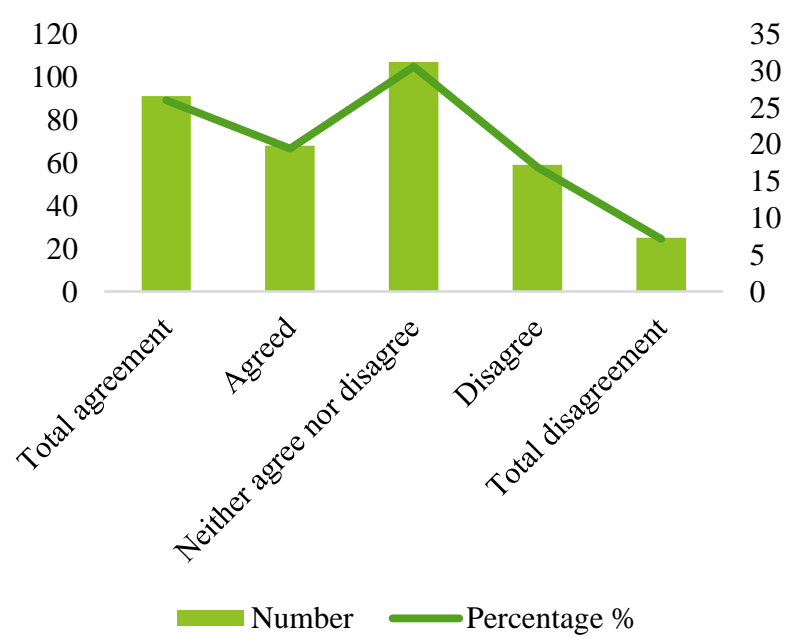

Graph 8 In my company, the commercialization of external technology is restricted to technologies that are not used internally

Source: Own Elaboration
The following table shows that $38 \%$ of the businessmen agree that external technologies in their company are restricted to those proven to be used in their institutions.

\begin{tabular}{|c|c|c|c|}
\hline Description & Number & $\begin{array}{c}\text { Percentage } \\
\%\end{array}$ & $\begin{array}{c}\text { Cumulative } \\
\text { Percentage \% }\end{array}$ \\
\hline Total agreement & 81 & 23.1 & 23.1 \\
\hline Agreed & 54 & 15.4 & 38.6 \\
\hline $\begin{array}{lll}\begin{array}{l}\text { Neither agree nor } \\
\text { disagree }\end{array} & \\
\end{array}$ & 118 & 33.7 & 72.3 \\
\hline Disagree & 60 & 17.1 & 89.4 \\
\hline Total disagreement & 37 & 10.6 & 100.0 \\
\hline Total surveys applied & 350 & 100.0 & \\
\hline
\end{tabular}

Table 10 In my organization, external technology is restricted to relatively mature and proven technologies Source: Own Elaboration

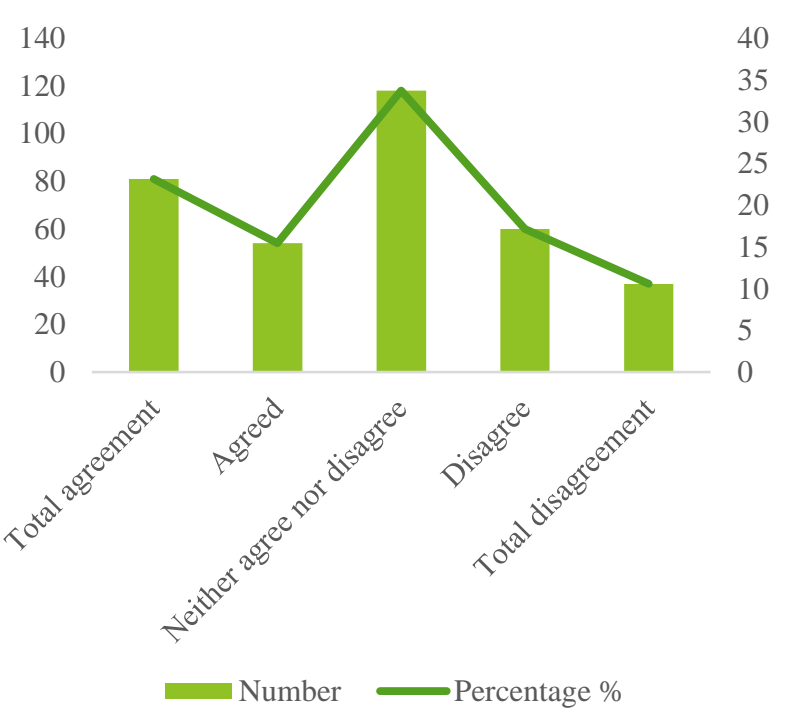

Graph 9 In my organization, external technology is restricted to relatively mature and proven technologies Source: Own Elaboration

This table shows that only $43.1 \%$ agree that their company acquires non-core technologies.

\begin{tabular}{|l|r|r|r|}
\hline \multicolumn{1}{|c|}{ Description } & Number & $\begin{array}{c}\text { Percentage } \\
\text { \% }\end{array}$ & $\begin{array}{c}\text { Cumulative } \\
\text { Percentage \% }\end{array}$ \\
\hline Total agreement & 88 & 25.1 & 25.1 \\
\hline Agreed & 63 & 18.0 & 43.1 \\
\hline $\begin{array}{l}\text { Neither agree nor } \\
\text { disagree }\end{array}$ & 123 & 35.1 & 78.3 \\
\hline Disagree & 50 & 14.3 & 92.6 \\
\hline Total disagreement & 26 & 7.4 & 100.0 \\
\hline Total surveys applied & 350 & 100.0 & \\
\hline
\end{tabular}

Table 11 In my company, the commercialization of external technology is restricted to non-special technologies

Source: Own Elaboration 


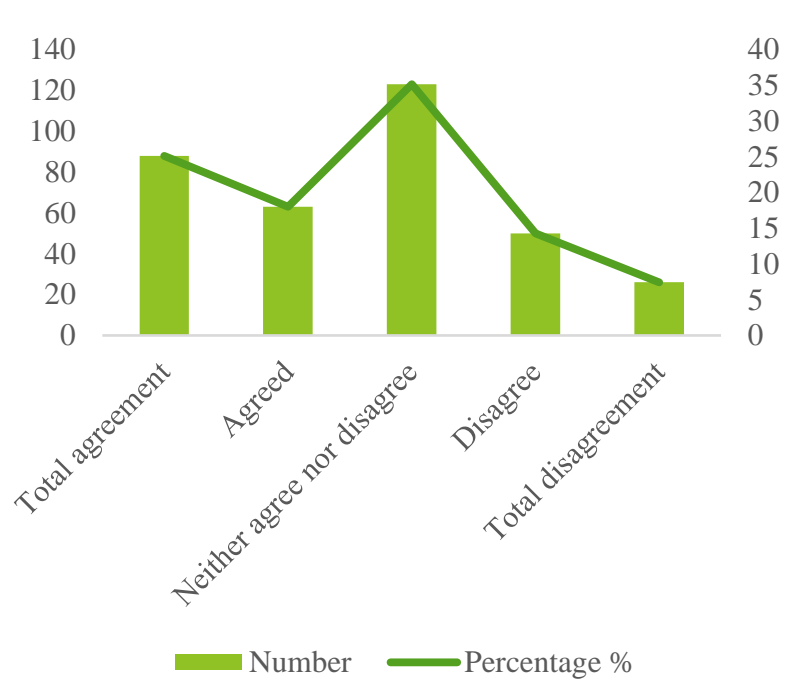

Graph 10 In my company, the commercialization of external technology is restricted to non-special technologies

Source: Own Elaboration

The following table shows that managers perceive that they have not given preference to good and cheap products. Only $10 \%$ agreed that they had acquired them.

\begin{tabular}{|l|r|r|r|}
\hline \multicolumn{1}{|c|}{ Description } & $\begin{array}{c}\text { Number } \\
\text { \% }\end{array}$ & $\begin{array}{c}\text { Percentage } \\
\text { Cumulative } \\
\text { Percentage \% }\end{array}$ \\
\hline Total agreement & 13 & 3.7 & 3.7 \\
\hline Agreed nor & 23 & 6.6 & 10.3 \\
\hline $\begin{array}{l}\text { Neither agree } \\
\text { disagree }\end{array}$ & 68 & 19.4 & 29.7 \\
\hline Disagree & 155 & 44.3 & 74.0 \\
\hline Total disagreement & 91 & 26.0 & 100.0 \\
\hline Total surveys applied & 350 & 100.0 & \\
\hline
\end{tabular}

Table 12 The company has given great importance to solutions that offer good and inexpensive services Source: Own Elaboration

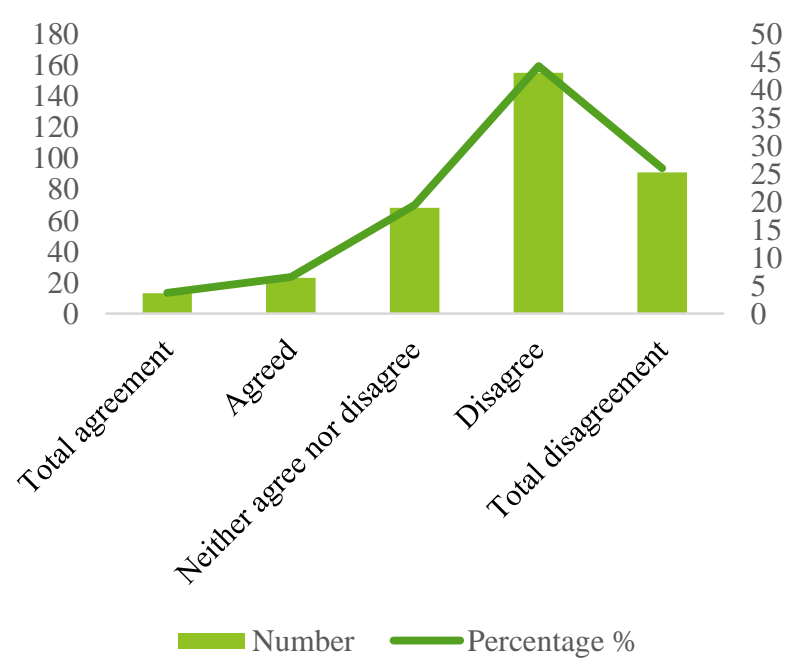

Graph 11 The company has given great importance to solutions that offer good and cheap services

Source: Own Elaboration
This table shows that the directors and managers perceive that they have lowered their costs in the operational process, $14.90 \%$ of the businessmen agree with this.

\begin{tabular}{|c|c|c|c|}
\hline Description & Number & $\begin{array}{c}\text { Percentage } \\
\%\end{array}$ & $\begin{array}{c}\text { Cumulative } \\
\text { Percentage \% }\end{array}$ \\
\hline Total agreement & 18 & 5.1 & 5.1 \\
\hline Agreed & 34 & 9.7 & 14.9 \\
\hline $\begin{array}{ll}\text { Neither agree nor } \\
\text { disagree }\end{array}$ & 103 & 29.4 & 44.3 \\
\hline Disagree & 131 & 37.4 & 81.7 \\
\hline Total disagreement & 64 & 18.3 & 100.0 \\
\hline Total surveys applied & 350 & 100.0 & \\
\hline
\end{tabular}

Table 13 In the last three years, in the development of its products and services, the company has given great importance to cost reduction in the operational process Source: Prepared by the company itself

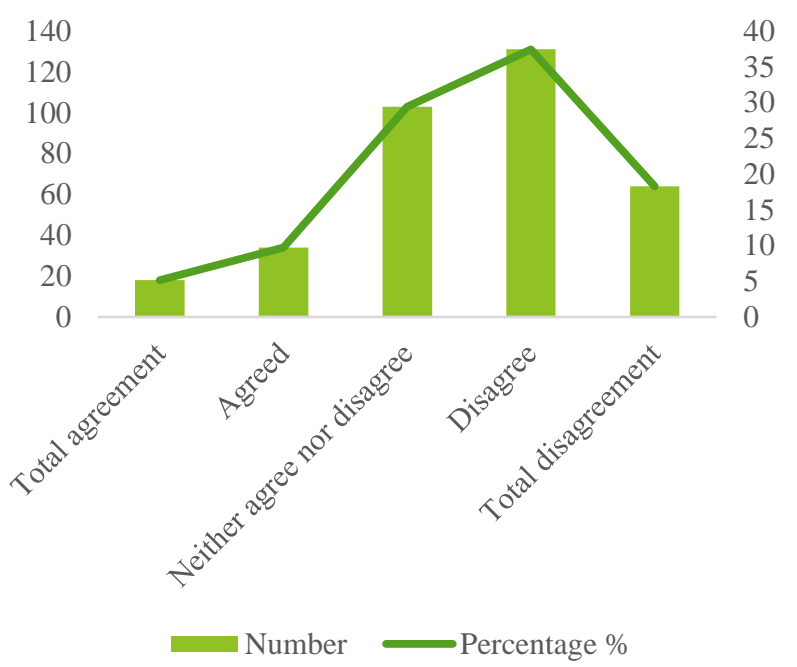

Graph 12 In the last three years in the development of its products and services, the company has given great importance to cost reduction in the operational process Source: Prepared by the company

This table shows that $13 \%$ agree that they have reduced their final price, which shows that most of the entrepreneurs have not reduced their final price in the last three years.

\begin{tabular}{|c|c|c|c|}
\hline Description & Number & $\begin{array}{c}\text { Percentage } \\
\%\end{array}$ & $\begin{array}{c}\text { Cumulative } \\
\text { Percentage \% }\end{array}$ \\
\hline Total agreement & 18 & 5.1 & 5.1 \\
\hline Agreed & 28 & 8.0 & 13.1 \\
\hline $\begin{array}{ll}\begin{array}{l}\text { Neither agree } \\
\text { disagree }\end{array} & \text { nor } \\
\end{array}$ & 94 & 26.9 & 40.0 \\
\hline Disagree & 140 & 40.0 & 80.0 \\
\hline Total disagreement & 70 & 20.0 & 100.0 \\
\hline Total surveys applied & 350 & 100.0 & \\
\hline
\end{tabular}

Table 14 Significant reduction in the final price Source: Own Elaboration

SERRANO-TORRES, Ma. Guadalupe, QUEZADA-FLORES, Ma. De la Luz, MARTINEZ-BECERRA, Abel Manuel and ZAMBRANO-VALDIVIEZO, Oscar Javier. Analysis of innovation in the MIPYMES of León, Guanajuato, Mexico, during and post-covid-19. Journal-Labor and Demographic economics. 2021 


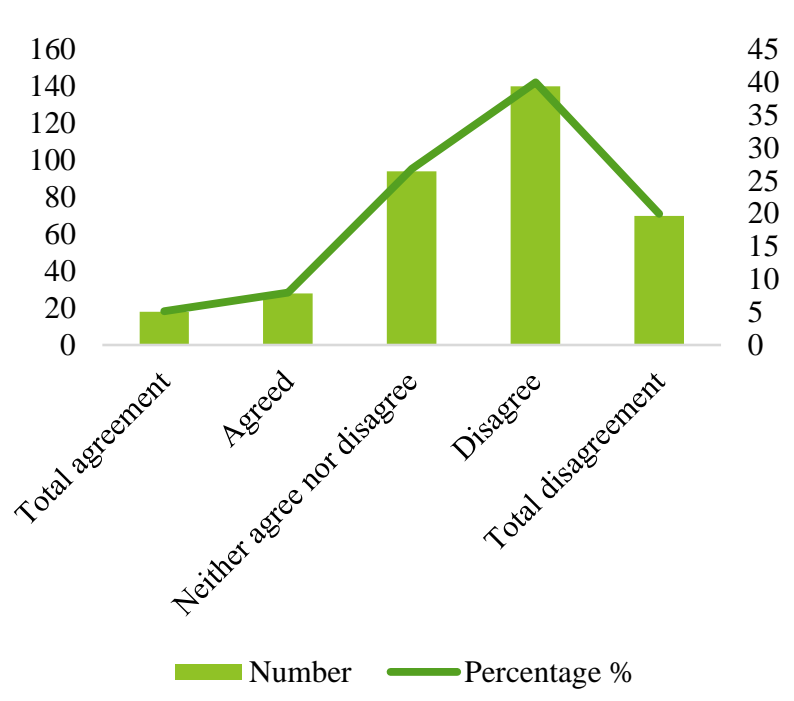

Graph 13 Significant reduction in final price Source: Own Elaboration

This table shows that $17.4 \%$ agree that they have invested in sustainability in the production of their products or services.

\begin{tabular}{|l|r|r|r|}
\hline \multicolumn{1}{|c|}{ Description } & \multicolumn{1}{r|}{$\begin{array}{r}\text { Number } \\
\text { \% }\end{array}$} & $\begin{array}{c}\text { Percentage } \\
\text { Percentage \% }\end{array}$ \\
\hline Total agreement & 27 & 7.7 & 7.7 \\
\hline Agreed nor & 34 & 9.7 & 17.4 \\
\hline $\begin{array}{l}\text { Neither agree nor } \\
\text { disagree }\end{array}$ & 103 & 29.4 & 46.9 \\
\hline Disagree & 110 & 31.4 & 78.3 \\
\hline Total disagreement & 76 & 21.7 & 100.0 \\
\hline Total surveys applied & 350 & 100.0 & \\
\hline
\end{tabular}

Table 15 Have invested in environmental sustainability Source: Own Elaboration

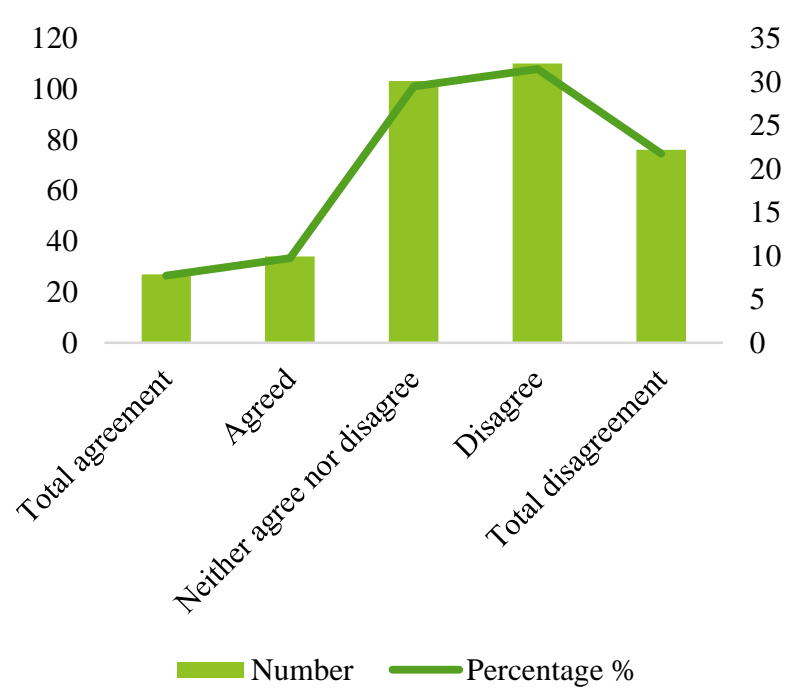

Graph 14 Have invested in environmental sustainability Source: Own Elaboration

In this table, $30 \%$ of the entrepreneurs agree that they have used alliances with local companies for the production of their products and services.

\begin{tabular}{|l|r|r|r|}
\hline \multicolumn{1}{|c}{ Description } & \multicolumn{1}{c}{ Number } & \multicolumn{1}{c|}{$\begin{array}{c}\text { Percentage } \\
\text { \% }\end{array}$} & $\begin{array}{c}\text { Cumulative } \\
\text { Percentage \% }\end{array}$ \\
\hline Total agreement & 53 & 15.1 & 15.1 \\
\hline Agreed nor & 54 & 15.4 & 30.6 \\
\hline $\begin{array}{l}\text { Neither agree no } \\
\text { disagree }\end{array}$ & 80 & 22.9 & 53.4 \\
\hline Disagree & 105 & 30.0 & 83.4 \\
\hline Total disagreement & 58 & 16.6 & 100.0 \\
\hline Total surveys applied & 350 & 100.0 & \\
\hline
\end{tabular}

Table 16 Have had alliances with local companies in the operational process

Source: Own Elaboration

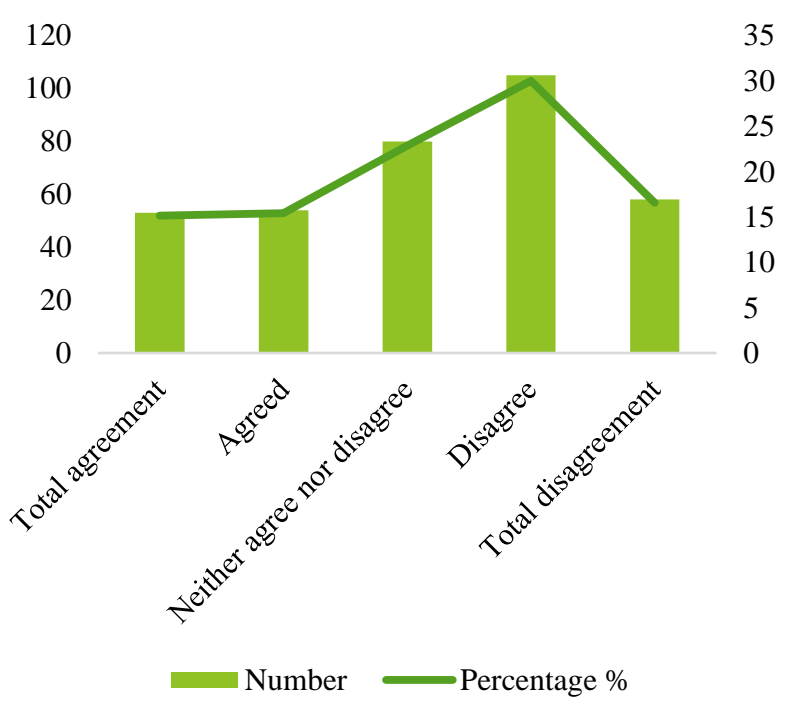

Graph 15 Have had alliances with local companies in the operational process

Source: Own Elaboration

This table shows that the managers and duels of MSMEs perceive in $15.4 \%$ and agree that they gave social and environmental solutions to their clients.

\begin{tabular}{|c|c|c|c|}
\hline Description & Number & $\begin{array}{c}\text { Percentage } \\
\%\end{array}$ & $\begin{array}{c}\text { Cumulative } \\
\text { Percentage \% }\end{array}$ \\
\hline Total agreement & 21 & 6.0 & 6.0 \\
\hline Agreed & 33 & 9.4 & 15.4 \\
\hline $\begin{array}{lll}\begin{array}{l}\text { Neither agree } \\
\text { disagree }\end{array} & & \\
\end{array}$ & 89 & 25.4 & 40.9 \\
\hline Disagree & 145 & 41.4 & 82.3 \\
\hline Total disagreement & 62 & 17.7 & 100.0 \\
\hline Total surveys applied & 350 & 100.0 & \\
\hline
\end{tabular}

Table 17 Efficient solutions have been provided to clients' social and environmental needs

Source: Prepared by the company 


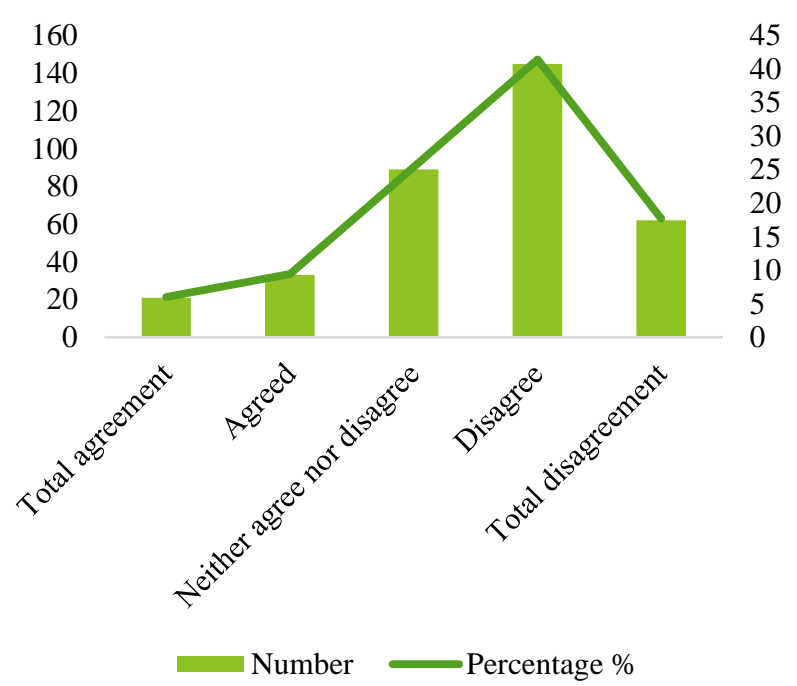

Graph 16 Efficient solutions have been provided to clients' social and environmental needs Source: Prepared by the company

This table shows that only $14 \%$ of the entrepreneurs agree that priority was given to investing in the additional function of product or service. And all the rest were dedicated to investing in the normal functionality of the product or service.

\begin{tabular}{|l|r|r|r|}
\hline \multicolumn{1}{|c|}{ Description } & \multicolumn{2}{c}{$\begin{array}{c}\text { Number } \\
\text { \% }\end{array}$} & $\begin{array}{c}\text { Percentage } \\
\text { Cumulative } \\
\text { Percentage \% }\end{array}$ \\
\hline Total agreement & 21 & 6.0 & 6.0 \\
\hline Agreed nor & 30 & 8.6 & 14.6 \\
\hline $\begin{array}{l}\text { Neither agree } \\
\text { disagree }\end{array}$ & 95 & 27.1 & 41.7 \\
\hline Disagree & 130 & 37.1 & 78.9 \\
\hline Total disagreement & 74 & 21.1 & 100.0 \\
\hline Total surveys applied & 350 & 100.0 & \\
\hline
\end{tabular}

Table 18 They have invested in the main functionality of the product rather than in additional functionality Source: Own Elaboration

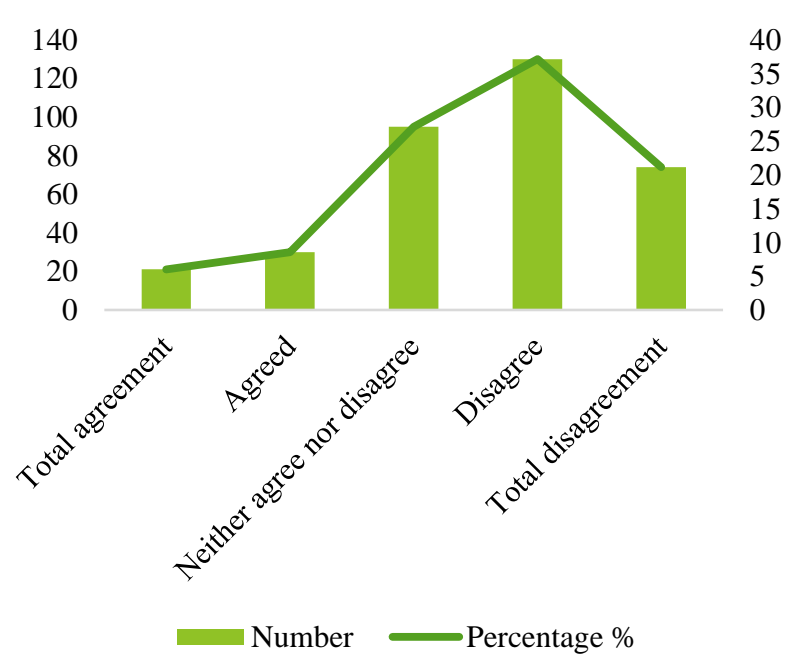

Graph 17 They have invested in the main functionality of the product instead of in the additional functional one Source: Own Elaboration
This table shows that $8.9 \%$ of the entrepreneurs have the perception that they have invested in the ease of use of the product or service.

\begin{tabular}{|l|r|r|r|}
\hline \multicolumn{1}{|c|}{ Description } & \multicolumn{1}{c}{ Number } & $\begin{array}{c}\text { Percentage } \\
\text { \% }\end{array}$ & $\begin{array}{c}\text { Cumulative } \\
\text { Percentage \% }\end{array}$ \\
\hline Total agreement & 7 & 2.0 & 2.0 \\
\hline Agreed & 24 & 6.9 & 8.9 \\
\hline $\begin{array}{l}\text { Neither agree nor } \\
\text { disagree }\end{array}$ & 59 & 16.9 & 25.7 \\
\hline Disagree & 147 & 42.0 & 67.7 \\
\hline Total disagreement & 113 & 32.3 & 100.0 \\
\hline Total surveys applied & 350 & 100.0 & \\
\hline
\end{tabular}

Table 19 They have invested in the ease of use of the product or service

Source: Own Elaboration

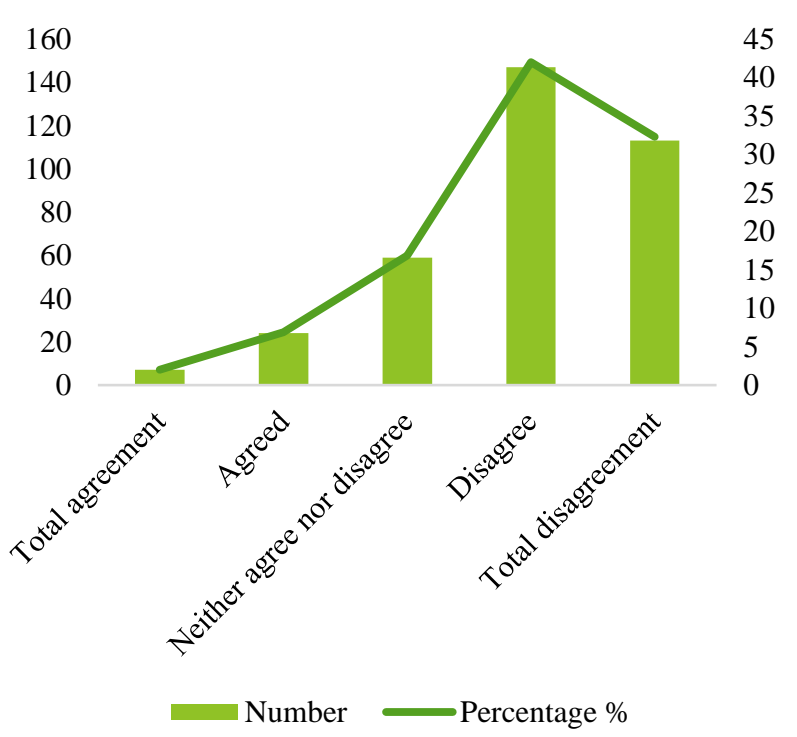

Graph 18 They have invested in the ease of use of the product or service

Source: Own Elaboration

This table shows that $12 \%$ of the entrepreneurs agree that they have invested in the durability of the product or service.

\begin{tabular}{|c|c|c|c|}
\hline Description & Number & $\begin{array}{c}\text { Percentage } \\
\%\end{array}$ & $\begin{array}{c}\text { Cumulative } \\
\text { Percentage \% }\end{array}$ \\
\hline Total agreement & 16 & 4.6 & 4.6 \\
\hline Agreed & 26 & 7.4 & 12.0 \\
\hline $\begin{array}{ll}\text { Neither agree nor } \\
\text { disagree }\end{array}$ & 63 & 18.0 & 30.0 \\
\hline Disagree & 136 & 38.9 & 68.9 \\
\hline Total disagreement & 109 & 31.1 & 100.0 \\
\hline Total surveys applied & 350 & 100.0 & \\
\hline
\end{tabular}

Table 20 They have invested in the durability of the product and service

Source: Own Elaboration 


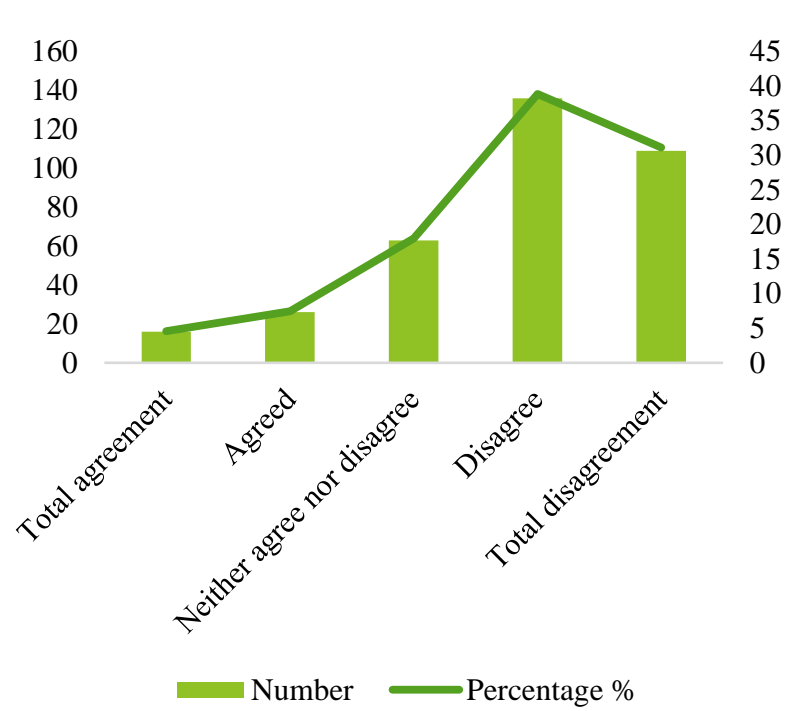

Graph 19 They have invested in the durability of the product and service

Source: Own Elaboration

The table above shows that $19.1 \%$ of the entrepreneurs agree that they have invested in the introduction of new products and services.

\begin{tabular}{|l|r|r|r|}
\hline \multicolumn{1}{|c|}{ Description } & \multicolumn{1}{r|}{$\begin{array}{r}\text { Number } \\
\text { \% }\end{array}$} & $\begin{array}{c}\text { Percentage } \\
\text { Percentage \% }\end{array}$ \\
\hline Total agreement & 28 & 8.0 & 8.0 \\
\hline Agreed nor & 39 & 11.1 & 19.1 \\
\hline $\begin{array}{l}\text { Neither agree nor } \\
\text { disagree }\end{array}$ & 97 & 27.7 & 46.9 \\
\hline Disagree & 132 & 37.7 & 84.6 \\
\hline Total disagreement & 54 & 15.4 & 100.0 \\
\hline Total surveys applied & 350 & 100.0 & \\
\hline
\end{tabular}

Table 21 Invested in the introduction of new products and services

Source: Own Elaboration

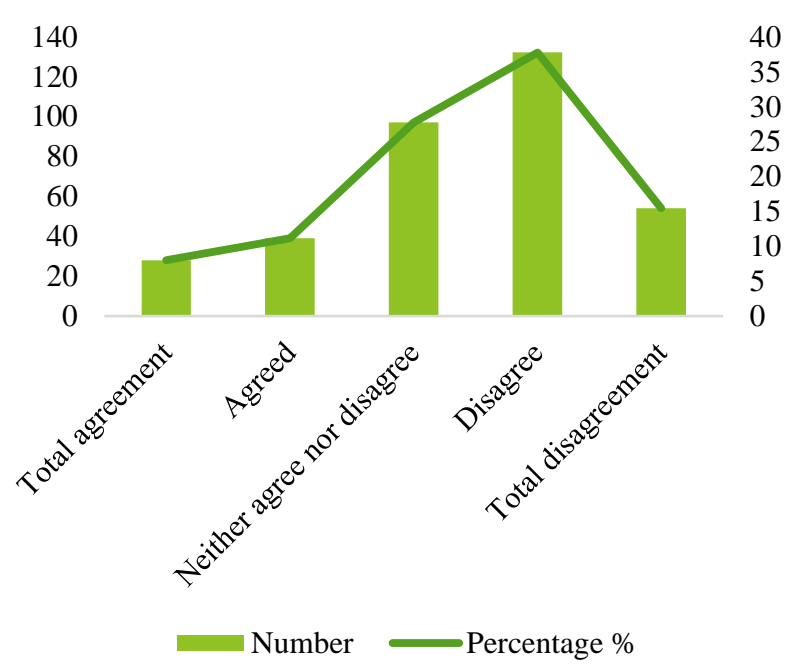

Graph 20 They invested in the introduction of new products and services

Source: Own Elaboration
This table shows that $20.6 \%$ of the entrepreneurs agree that they invested in the development of new production processes for their product or service.

\begin{tabular}{|c|c|c|c|}
\hline Description & Number & $\begin{array}{c}\text { Percentage } \\
\%\end{array}$ & $\begin{array}{l}\text { Cumulative } \\
\text { Percentage \% }\end{array}$ \\
\hline Total agreement & 30 & 8.6 & 8.6 \\
\hline Agreed & 42 & 12.0 & 20.6 \\
\hline $\begin{array}{lll}\text { Neither agree nor } \\
\text { disagree }\end{array}$ & 124 & 35.4 & 56.0 \\
\hline Disagree & 104 & 29.7 & 85.7 \\
\hline Total disagreement & 50 & 14.3 & 100.0 \\
\hline Total surveys applied & 350 & 100.0 & \\
\hline
\end{tabular}

Table 22 Invested in the introduction of new production methods

Source: Own Elaboration

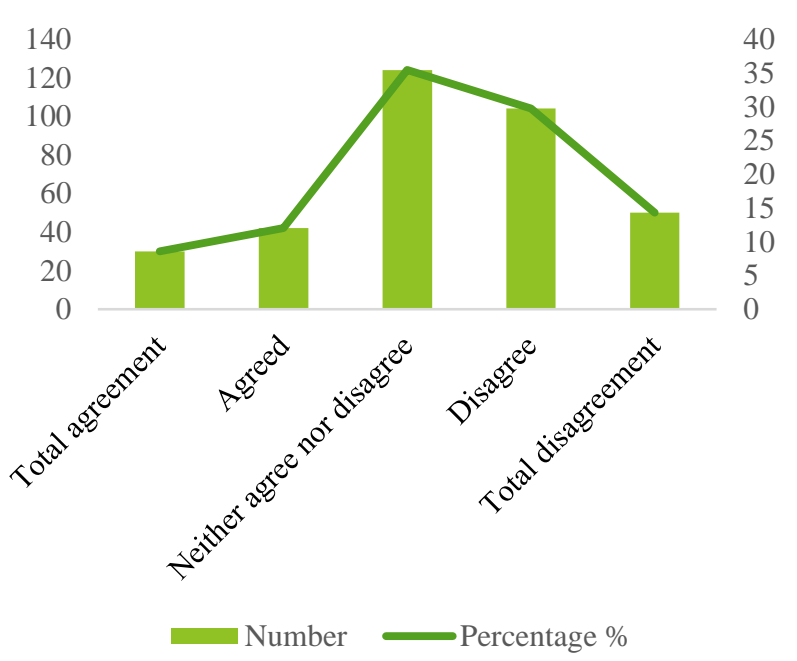

Graph 21 Invested in the introduction of new production methods

Source: Own Elaboration

This table shows that only $11.10 \%$ of the entrepreneurs perceive that they are innovative in comparison to their main competitors, the other entrepreneurs do not perceive innovation better than their competitors.

\begin{tabular}{|c|c|c|c|}
\hline Description & Number & $\begin{array}{c}\text { Percentage } \\
\%\end{array}$ & $\begin{array}{c}\text { Cumulative } \\
\text { Percentage \% }\end{array}$ \\
\hline Total agreement & 15 & 4.3 & 4.3 \\
\hline Agreed & 24 & 6.9 & 11.1 \\
\hline $\begin{array}{ll}\begin{array}{l}\text { Neither agree nor } \\
\text { disagree }\end{array} & \\
\end{array}$ & 119 & 34.0 & 45.1 \\
\hline Disagree & 120 & 34.3 & 79.4 \\
\hline Total disagreement & 72 & 20.6 & 100.0 \\
\hline Total surveys applied & 350 & 100.0 & \\
\hline
\end{tabular}

Table 23 Compared to our competitors, our company has become more innovative Source: Own Elaboration 


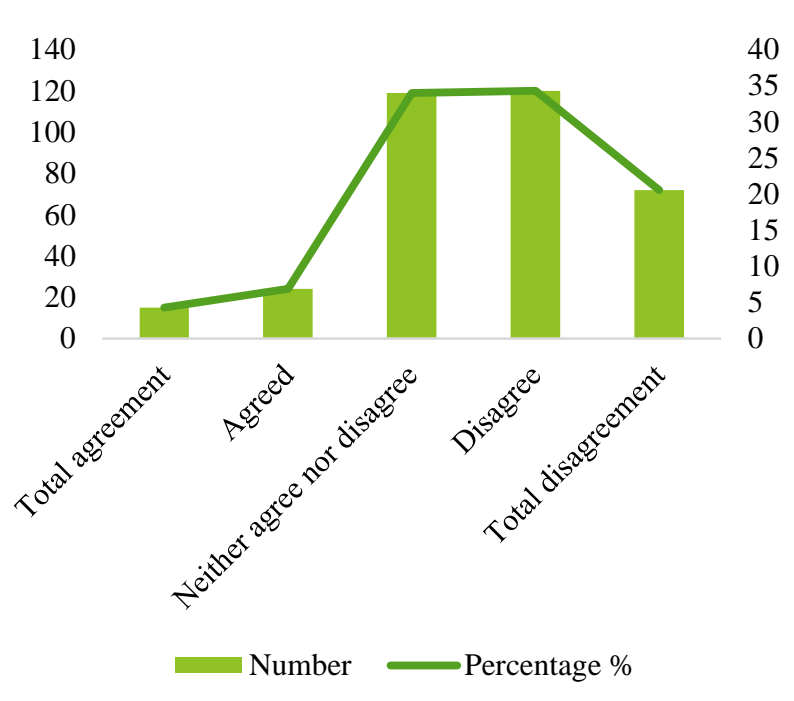

Graph 22 Compared to our competitors, our company has become more innovative

Source: Own Elaboration

\section{Acknowledgment}

We would like to thank the Universidad Tecnologica de León and the Research Network of Technological Universities for the generation of this project and the application of the national surveys on productivity during and after covid19.

\section{Discussion and conclusions}

Analyzing the annovae of this research we have the following;

Open innovation is $60.4 \%$ correlated with frugal innovation and is significant at $99 \%$ reliability.

Open innovation is $58 \%$ correlated with innovation outcome and is significant at $99 \%$ reliability.

Frugal innovation is $60.8 \%$ correlated with innovation performance and is significant at $99 \%$ reliability.

As an instrument of survival of the companies in this research, innovation is indispensable during and post covid-19.

There is a lack of investment by the entrepreneurs of MSMEs in open innovation, approaching research groups in each of their sectors and universities to receive technological and innovation support to develop their products and services as well as how to market and acquire their raw materials.
Frugal innovation requires the social commitment of entrepreneurs to offer products and services to their customers while caring for and protecting the environment.

Open and frugal innovation were significant in this research because it requires investment in innovation and urgent investment in technology to digitize and make production and marketing processes faster and more efficient, during and after the pandemic because the economic and health consequences will remain for several years around the world.

\section{References}

Basu, R. R., Banerjee, P. M., y Sweeny, E. G. (2013). Frugal innovation: core competencies to address global sustainability. Journal of Management for Global sustainability, 1(2), 6382 Recuperado en; file:///C:/Users/gserrano/Downloads/Captulo_1 7.pdf

Blancas (2020), Expansión, "Cierre de COVID19 en México", recuperado en; https://politica.expansion.mx/mexico/2020/12/3 1/covid-19-mexico-cierra-el-ano-con-125-807muertes-y-1-millon-426-094casos?utm_source=push_notification

Calderón M. (2010), El valor estratégico de los acuerdos de colaboración para la adquisición de conocimiento en procesos abiertos de innovación. Universidad Complutense de Madrid, España, recuperado en; https://www.scielo.cl/scielo.php?script=sci_artt ext\&pid=S0718-50732017000200006

CEPAL. (2021). "Análisis de las políticas de apoyo a las pymes para enfrentar la pandemia", recuperado en; https://repositorio.cepal.org/bitstream/handle/11 362/46743/1/S2100104_es.pdf

CEPAL. (2021) "Transformación digital de las mipymes". Recuperado en; https://repositorio.cepal.org/bitstream/handle/11 362/47183/1/S2100372_es.pdf

Directivos y gerentes (2021), "El 67\% de las mipymes reconocen el uso de tecnologías", recuperado https://directivosygerentes.es/pymes/67-porciento-pymes-reconoce-importancia-nuevastecnologias. 
ICE (2021). "Indices de competitvidad estatal 2021". Recuperado en; https://imco.org.mx/resultados-del-indice-decompetitividad-estatal-ice-2021/

Idconline, "Como las mipymes están utilizando la tecnología para recuperarse". Recuperado de; https://idconline.mx/corporativo/2021/06/29/co mo-las-pymes-estan-adoptando-la-tecnologiapara-recuperarse

IMCO (2021). "Indices Internacionales de competitividad 2021". Recuperado en; https://imco.org.mx/indice-de-competitividadinternacional-2021/

Maravato (2020), Expansión "El efecto covid19, en las PYMES, recuperado en: https://expansion.mx/opinion/2020/06/12/elefecto-covid-19-en-las-pymes.

Olguin (2021). "Sostenibilidad de MIPYMES en la pandemia apoyadas por el comercio electrónico". Recuperado en; http://www.web.facpya.uanl.mx/vinculategica/ Vinculategica6_2/53_Olguin_Barrera_Placeres. pdf

Diario el País, "México confirma el primer caso de ómicron en el país". Recuperado en; https://elpais.com/mexico/2021-12-03/mexicoconfirma-el-primer-caso-de-omicron-en-elpais.html.

Laursen K. and Salter A. (2006), Open for innovation: The role of openness in explaining innovation performance among U.K. manufacturing firms. Strategic Management Journal, 27(2), 131-150. Recuperado en; https://www.scielo.cl/scielo.php?script=sci_artt ext\&pid=S0718-50732017000200006

Proum, (2020), Forbes, "El estornudo del COVID-19 en las MIPYMES, Mexicanas", recuperado de: https://www.forbes.com.mx/elestornudo-del-covid-19-en-las-pymesmexicanas/

NEUBOX, (2021), “Las cinco ciudades más innovadoras de México", Recuperado en; https://neubox.com/blog/las-5-ciudades-mastecnologicas-de-mexico/

WIPO, (2021), “Global innovatión Index 2021", recuperado de; https://www.wipo.int/edocs/pubdocs/en/wipo_p ub_gii_2021.pdf

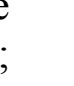

